\title{
Growth curve of Repartida goats reared in the Caatinga region, Brazil
}

\section{Curva de crescimento de caprinos Repartida criados na Caatinga}

\author{
Luanna Chácara Pires ${ }^{1 *}$; Théa Mírian Medeiros Machado²; \\ Paulo Luiz Souza Carneiro ${ }^{3}$; João Batista Lopes da Silva'; \\ Andréa Duarte de Holanda Barbosa ${ }^{3}$; Robledo de Almeida Torres ${ }^{2}$
}

\begin{abstract}
This work aimed to determine which non-linear model (Brody, Gompertz, logistic, von Bertalanffy or Richards) best represents the average growth curve of goats, in addition to evaluating the effect of the environment. The weight data of 40 Repartida goats reared in the Brazil Caatinga were included in this study. Weight data was collected every 30 days from birth until 270 days of age. The parameters of the models ( $A$, mature body weight; $B$, constant of integration; $k$, maturation rate; $m$, inflection point) were estimated using the NLIN procedure of SAS. The logistic model showed a slightly higher average fit in comparison to the other models. The absolute growth rate suggests that the maximum growth rate was reached early. The effect of the contemporary groups was significant $(\mathrm{P}<0.05)$, but only for the estimated $k$ parameter. The estimated correlation between the $A$ and $k$ parameters was significant and negative, indicating a lower probability of a high body weight in adulthood. Goats of the Repartida ecotype are characterized by their high birth weight and low weight at maturity, which combined with the nutritional deficit, suggests that these animals have adapted to the adverse conditions of the Brazilian Caatinga region.
\end{abstract}

Key words: Body weight. Growth rate. Naturalized goats. Brazil Caatinga.

\section{Resumo}

Objetivou-se neste trabalho verificar dentre os modelos não-lineares seguintes, Brody, Gompertz, Logístico, Von Bertalanffy e Richards, qual representa melhor a curva média de crescimento de caprinos e, também, avaliar a influência do ambiente nos parâmetros estimados. Para a condução deste trabalho foram utilizados registros de peso de 40 caprinos do ecótipo Repartida criados na caatinga, coletados a cada 30 dias entre o nascimento até os 270 dias de idade. Os parâmetros dos modelos (A, peso à idade adulta; $\mathrm{B}$, constante de integração; $\mathrm{k}$, taxa de maturação; e $\mathrm{m}$, ponto de inflexão) foram estimados com o procedimento NLIN do software SAS. O modelo Logístico apresentou ajuste médio ligeiramente superior aos demais modelos. Os resultados obtidos para taxa de crescimento absoluto indicam que a taxa máxima de crescimento foi alcançada precocemente. $\mathrm{O}$ efeito de grupos contemporâneos foi significativo $(\mathrm{P}<0,05)$ somente para o parâmetro k estimado. A correlação estimada entre os parâmetros A e k foi significativa e negativa, indicando menor probabilidade dos caprinos atingirem pesos elevados à idade adulta. Os caprinos do ecótipo Repartida são de alto peso ao nascimento e baixo peso à maturidade, o que pode indicar, além do déficit nutricional, a adaptação desses animais às condições adversas da caatinga.

Palavras-chave: Peso corporal. Taxa de crescimento. Caprinos naturalizados. Caatinga.

\footnotetext{
${ }^{1}$ Prof ${ }^{\text {as }}$, Universidade Federal do Sul da Bahia, UFSB, Instituto de Humanidades, Artes e Ciências, Campus Paulo Freire, Teixeira de Freitas, BA, Brasil. E-mail: luanna.ufsb@gmail.com; silvajbl@ufsb.edu.br

2 Prof ${ }^{\text {as }}$, Universidade Federal de Viçosa, UFV, Departamento de Zootecnia, Campus Viçosa, Viçosa, MG, Brasil. E-mail: thea@ ufv.br; rtorres@ufv.br

3 Profs., Universidade do Sudoeste da Bahia, UESB, Departamento de Ciências Biológicas, Campus Jequié, Jequié, BA, Brasil. E-mail: plscarneiro@gmail.com; deinhavet@yahoo.com.br

* Author for correspondence
} 


\section{Introduction}

The number of goats in Brazil is almost 9 million (IBGE, 2014). The Northeast of Brazil contains over $93 \%$ of the effective herd of goats in the country, in addition to $58 \%$ of the sheep. These animals are predominantly created in little properties, what impeding the implementation of genetic improvement programs. The socio-economic importance of goats in Northeast Brazil is evident, as the milk and meat are used to feed the primarily middle- and low-income population of this region (SILVA; ARAÚJO, 2000).

The breeds and naturalized goats are mainly located in the Northeast of Brazil, originally brought to this region by settlers. Due to the harsh environmental conditions, these goats underwent natural selection, resulting in animals with the ability to survive and breed in this region. The adaption of these animals to this environment is the main reason for the conservation and future exploration of their genetic potential.

Repartida goats, described by Freitas (1951), are characterized by black fur on the front of the body and red fur on the back, in addition to medium-sized horns. Animals with an inverted colored phenotype, originally called Meísta, were later also considered to be Repartida (DOMINGUES, 1941). According to Machado (2001), a cross between the Repartida and Meísta breeds may have mischaracterized these animals based on their fur, consequently reducing their number. Few studies have focused on the Repartida ecotype, therefore, information on the average value of their productivity indexes is limited. Currently, there is only one flock of this breed in the Bahia Company of Agricultural Development (Empresa Baiana de Desenvolvimento Agrícola, EBDA), therefore, its conservation is important (MACHADO; MACHADO, 2000).

Growth curves are used to describe the development of animals over time, assisting in the establishment of nutrition programs and in determining the optimum age for slaughter
(OLIVEIRA et al., 2000). Brody, Gompertz, logistic, Richards and von Bertalanffy models are the most commonly used models used to describe the growth of several species of domestic animals (MONTEIRO et al., 1998; MALHADO et al., 2008; SARMENTO et al., 2008; CARNEIRO et al., 2009; OLIVEIRA et al., 2009). There have been no previous studies which have described the development of the Repartida goats over time, therefore, modeling the average growth curves of these animals is relevant and important. Once the model which best fits the data has been identified, it is possible to verify and predict changes in animal growth, as well as meat production.

Therefore, the aim of this study was to determine the non-linear models that best fit the growth data, and use these models to calculate the absolute growth curves in goats of the Repartida ecotype.

\section{Materials and Methods}

The herd evaluated in this study, belonging to the EBDA, was composed of 40 goats of the Repartida ecotype, all of which had been reared in the semiarid Caatinga (Jaguarari-BA) region of Brazil. This region has an average annual precipitation of 577,4 $\mathrm{mm}$ and average annual temperature of between 21,4 to $32,5^{\circ} \mathrm{C}$ (INMET, 2016), similar to a savanna climate. The goats were supplemented with mineral salt and palm (Opundia ficus indica) during the driest periods of the year. The data collected included their date of birth, mother, type of birth (single, double or triple birth), sex (male or female) and body weight. This information was collected every 30 days from birth until 270 days of age.

Five non-linear models were compared and fitted to the body weight data (Table 1). In these models $y$ is the body weight ( $\mathrm{kg}$ ) at age $t ; A$ is the asymptotic weight when $t$ is unlimited, interpreted as the adult weight; $B$ is an integration constant, related to the initial weight of the animal, without biological interpretation, where $B$ is established from the initial values of $y$ and $t ; k$ is the maturation rate, indicating 
the speed at which the animal approaches its adult weight; $m$ is the parameter used to determine the form of the curve, and therefore, the inflection point; and $\varepsilon$ is the residual error.

The parameter estimation for each of the nonlinear models was performed using an iterative process with arbitrary initial values. At each step the sum of squared error was calculated, thereby obtaining a set of updated estimates until convergence at an estimated final vector with a minimum sum of squared error (SARMENTO et al., 2006). The iterative method used in this study was the Gauss-Newton method, which was modified using the NLIN procedure in SAS 9.0 (SAS, 1999). The convergence criteria adopted was $10^{-8}$.

Table 1. General form of the non-linear models.

\begin{tabular}{cc}
\hline Model & General equation \\
\hline Brody (BRODY, 1945) & $y=A\left(1-B e^{-k t}\right)+\varepsilon$ \\
von Bertalanffy (von BERTALANFFY, 1957) & $y=A\left(1-B e^{-k t}\right)^{3}+\varepsilon$ \\
Richards (RICHARDS, 1959) & $y=A\left(1-B e^{-k t}\right)^{m}+\varepsilon$ \\
Logistic (NELDER, 1961) & $y=A\left(1-B e^{-k t}\right)^{-m}+\varepsilon$ \\
Gompertz (LAIRD, 1965) & $y=A e^{B e^{(-k t)}+\varepsilon}$ \\
\hline
\end{tabular}

The criteria used to evaluate the models that best described the growth curve were: 1) mean square error (MSE); 2) coefficient of determination $\left(\mathrm{R}^{2}\right) ; 3$ ) percent convergence $(\mathrm{C})$, in which the existence or non-existence of the convergence was considered; 4) graphical analysis of models using the observed average weight; and 5) mean absolute deviation (MAD) statistic, as proposed by Sarmento et al. (2006), used to assess the quality of fit. The MAD was calculated as MAD $=\sum\left(y_{i}-\hat{y}_{i}\right) / n$, where $y_{i}$ is the observed value, $\hat{\mathrm{y}}_{i}$ is the estimated value and $n$ is the sample size. Thus, the lower the value of the MAD, the better the fit of the model.

After the model was selected, the absolute growth rate (AGR) obtained from the first derivative of the fitted model was calculated in relation to time $(\partial Y / \partial t)$. The AGR is the weight gain per unit of time $(t)$, where $t$ represented the time in days, therefore, the AGR described the daily weight gain.

The parameters $A, B, k$ and $m$, estimated for each animal depending on the fitted model, were analyzed using the GLM and the CORR procedures in SAS (1999) in order to verify the effects of the environment and any correlations between the estimated parameters. After the convergence of all models was verified, their respective values for the quality of fit criteria (quality assessor) were subjected to a cluster analysis using the CLUSTER procedure of SAS (1999), using the centroid method. We evaluated the effect of sex, type of birth (single, double or triple) and contemporary group on the curve parameters of the selected model. The contemporary groups included the birth season (1 or 2), in which season 1 corresponded to the rainy season (March to July) and season 2 corresponded to the dry season (August to February).

\section{Results and Discussion}

The mean and standard deviation of the body weight from birth to 270 days is shown in Table 2. The body weight at birth $(5.18 \mathrm{~kg})$ for goats of the Repartida ecotype, reared in the Caatinga, has previously been reported to be higher than that of the Mambrino breed (CARNEIRO et al., 2009). Both Repartida and Mambrino goats share the same place of rearing, however, the performance of the Repartida goats was lower after birth. The 
performance of the Repartida ecotype at 196 days of age has been reported to be lower than the Alpine breed, which are reared in a semi-arid region in Paraíba (OLIVEIRA, 2011). We observed that the weight of Repartida goats at 270 days of age was low compared to that reported by other authors.
Carneiro et al. (2009) reported that goats of the Mambrino breed weighed $23.41 \mathrm{~kg}$ at 270 days of age. Furthermore, Oliveira et al. (2009) evaluated goats of the Anglo-Nubian breed and reported an average body weight of $37.0 \mathrm{~kg}$ in males and 35.1 $\mathrm{kg}$ in females at 240 days of age.

Table 2. Mean and standard deviation of the observed body weight at birth (PN) and at 30 (P30), 60 (P60), 90 (P90), 120 (P120), 150 (P150), 180 (P180), 210 (P210) 240 (P240) and 270 (P270) days of age, for goats of the Repartida ecotype that were reared in the Caatinga region of Bahia, Brazil.

\begin{tabular}{lcccccccccc}
\hline Body weight & PN & P30 & P60 & P90 & P120 & P150 & P180 & P210 & P240 & P270 \\
\hline Mean (kg) & 5.18 & 6.62 & 8.85 & 10.21 & 10.72 & 11.52 & 12.70 & 14.38 & 15.10 & 15.40 \\
Standard deviation $(\mathrm{kg})$ & 1.14 & 1.71 & 2.16 & 2.20 & 2.69 & 2.19 & 2.24 & 2.75 & 3.81 & 3.10 \\
\hline
\end{tabular}

Goats of the Repartida ecotype are characterized by their high body weight at birth compared with goats of other breeds (CARNEIRO et al., 2009; OLIVEIRA et al., 2009; OLIVEIRA, 2011). However, the higher birth weight was not associated with a higher yield at maturity, as the increased weight displayed at birth was no longer present at weaning (P60) or in adulthood.

The criteria used to compare the predicted growth curves of the different models, in addition to the parameter estimates, are presented in Table 3. The estimate for asymptotic weight is represented by the parameter $A$, which was interpreted as the adult body weight of the animal. Estimates for parameter $A$ in goats of the Repartida ecotype were higher for the Richards (34.15), Brody (29.68) and von Bertalanffy (25.43) models, followed by the Gompertz (24.50) and logistic (22.31) models (Table 3). Similar results have also been reported by Sarmento et al. (2008) and Oliveira (2011) for Anglo-Nubian goats reared in Paraíba, in which the highest estimates for $A$ were from the Richards (31.47 and 30.66, respectively), Brody (28.23 and 29.63, respectively) and von Bertalanffy (22.55 and 26.51, respectively) models. Malhado et al. (2008) studied Anglo-Nubian goats reared in the Caatinga region of Bahia, and also reported higher estimates of $A$ for the Richards (42.96), Brody (42.58) and von Bertalanffy (37.45) models. For goats of the Mambrino breed that were reared in the same region, Carneiro et al. (2009) reported higher estimates for the Richards (34.52), von Bertalanffy (32.88) and Brody (32.17) models.

Table 3. Estimates of the parameters $(A, B, k$ and $m)$, mean square error (MSE), coefficient of determination $\left(\mathrm{R}^{2}\right)$, percent convergence $(C)$ and mean absolute deviation (MAD) in the growth curves of goats of the Repartida ecotype, as predicted by the non-linear Brody, von Bertalanffy, Richards, logistic and Gompertz models.

\begin{tabular}{lcccccccc}
\hline \multirow{2}{*}{ Models } & \multicolumn{9}{c}{ Parameters } & \multirow{2}{*}{ MSE } & \multirow{2}{*}{$\mathrm{R}^{2}$} & \multirow{2}{*}{ C (\%) } & \multirow{2}{*}{ MAD } \\
\cline { 2 - 4 } & $A$ & $B$ & $k$ & $m$ & & & \\
\hline Brody & 29.6808 & 0.7582 & 0.0066 & - & 1.6491 & 0.8753 & 61.7647 & 0.8086 \\
von Bertalanffy & 25.4332 & 0.3788 & 0.0090 & - & 1.6612 & 0.8858 & 76.4706 & 0.7527 \\
Richards & 34.1504 & 0.8031 & 0.1447 & 0.0300 & 1.3152 & 0.8988 & 58.8235 & 0.7765 \\
Logistic & 22.3116 & - & 0.0142 & 2.0026 & 1.2353 & 0.9147 & 85.2941 & 0.6533 \\
Gompertz & 24.4963 & 1.4460 & 0.0108 & - & 1.2821 & 0.9097 & 85.2941 & 0.6763 \\
\hline
\end{tabular}


The parameter $k$ influences the maturation rate of the animal, indicating the growth rate to reach the asymptotic weight. The models that obtained the highest estimates for $k$ were the Richards (0.1447), logistic (0.0142) and Gompertz (0.0108) models, whereas the lowest estimates for $k$ were from the Brody (0.0066) and von Bertalanffy (0.0090) models. Malhado et al. (2008) and Carneiro et al. (2009) obtained similar results in relation to the $k$ parameter, with the highest value reported for the Richards model ( 0.028 and 0.210 , respectively), followed by the logistic (0.017 and 0.014 , respectively), Gompertz (0.013 and 0.012, respectively), von Bertalanffy (0.011 and 0.010, respectively) and Brody (0.006 and 0.007, respectively), models. Conflicting results were reported by Sarmento et al. (2008) for the Anglo-Nubian breed, in which a higher $k$ value was reported for the logistic model (0.023), followed by the Gompertz $(0.014)$, von Bertalanffy (0.011), Brody (0.005) and Richards (0.004) models. Carneiro et al. (2009) reported that animals with a higher $k$ value matured earlier than animals of a similar weight with a smaller $k$ value.
The highest $\mathrm{R}^{2}$ values were observed in the logistic (0.9147), Gompertz (0.9097) and Richards (0.8988) models (Table 3 ). Similarly, these models presented the lowest estimates for MSE. The lowest values for MAD were observed in the logistic (0.6533), Gompertz (0.6763) and von Bertalanffy (0.7527) models.

In their study, Souza and Bianchini Sobrinho (1994) emphasized that the greater number of individual convergence in relation to the total number of animals, the better the fit of the model. The convergence rate for the Gompertz and logistic models were higher than $85 \%$, and therefore, these models best explained the growth of the animals, while the von Bertalanffy model obtained a convergence of $76.47 \%$.

The quality assessor results for the fit of the model was confirmed by cluster analysis, in which we observed the formation of two groups (Figure 1), one composed of the Gompertz, logistic and von Bertalanffy models and another of the Brody and Richards models.

Figure 1. Dendrogram obtained by the centroid clustering method, based on the quality assessors (MSE - mean square error; $\mathrm{R}^{2}$ - coefficient of determination; $\mathrm{C}$ - percent convergence; and MAD - mean absolute deviation) for the (A) Brody, (B) von Bertalanffy, (C) Richards, (D) logistic and (E) Gompertz models.

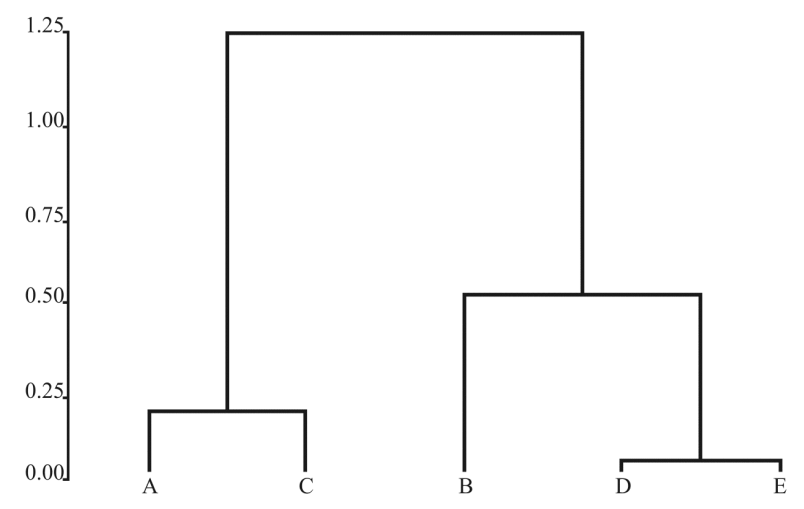

Based on the MAD, small deviations were observed for all models, however, the lowest value was observed in the logistic model (0.6533), indicating a better average fit when compared with the Gompertz and von Bertalanffy models (0.6763 and 0.7527 , respectively). Based on the average absolute deviations of the residues, we found that the logistic model showed a slightly better average fit than the Gompertz model for describing the growth of Repartida goats. This result is in agreement with 
that previously reported by Carneiro et al. (2009), who reported that the logistic model showed a better fit for describing the growth curve of Mambrino goats. Sarmento et al. (2008), Malhado et al. (2008) and Oliveira et al. (2009) found that the Brody, von Bertalanffy and logistic models, respectively, showed the best fit for the data for Anglo-Nubian goats raised in distinct regions of Northeast Brazil, giving estimated values closer to the observed values at all ages on the growth curve.

The estimated growth curves for the Gompertz, logistic and von Bertalanffy models obtained in the current study are shown in Figure 2, and the estimated growth curves for the Brody and Richards models are shown in in Figure 3. The growth curve estimated by the logistic model best described the average growth of goats of the Repartida ecotype. Although this model estimated a lower body weight at birth and throughout the aging process, the predicted values were more consistent and closer to the actual values. The next best model for estimating the growth curve was the logistic model, and the curve that best described the growth of goats in this study was the Gompertz model (Figure 2). The growth curves estimated by the Brody and Richards models overestimated the birth weight until adulthood (Figure 4).

Figure 2. Estimated body weight of goats of the Repartida ecotype, reared in the Brazilian Caatinga region, based on age and adjusted using the logistic, Gompertz and von Bertalanffy models.

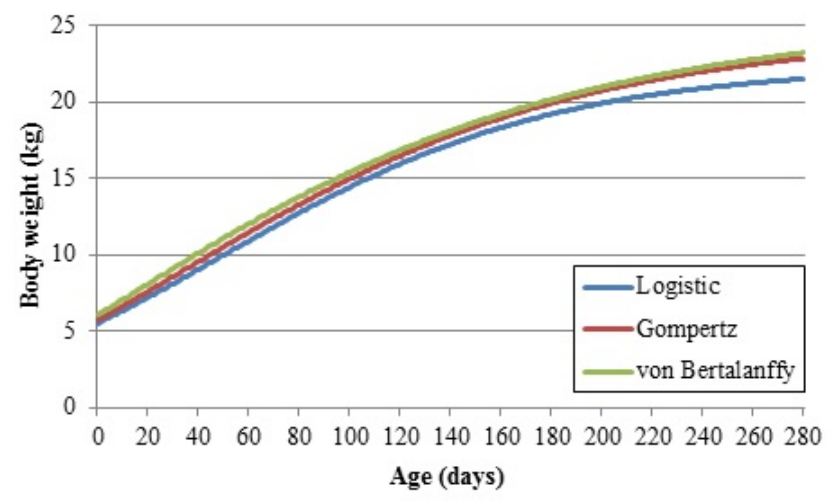

Figure 3. Estimated body weight of goats of the Repartida ecotype, reared in the Brazilian Caatinga region, based on age and adjusted using the Brody and Richards models.

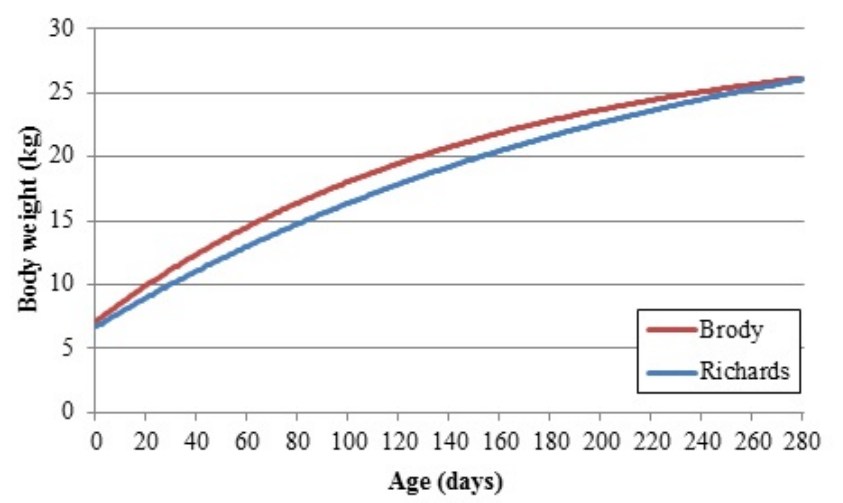


The AGR was obtained using the first derivative of the logistic model in relation to time (Figure 4). The AGR was crescent-shaped until it reached its maximum rate at 50 days of $9.39 \mathrm{~g}$ per day, after which the rate decreased-shaped with age. During this phase, the growth rate was high and positive, peaking at the point of inflection of the curve. After this point the function changed from increasing to decreasing, and the inflection point was reached at 70 days of age, at which the goats weighed approximately $11.88 \mathrm{~kg}$.

Figure 4. Absolute growth rate (AGR), as estimated by the logistic function, of goats of the Repartida ecotype that were reared in the Brazilian Caatinga region.

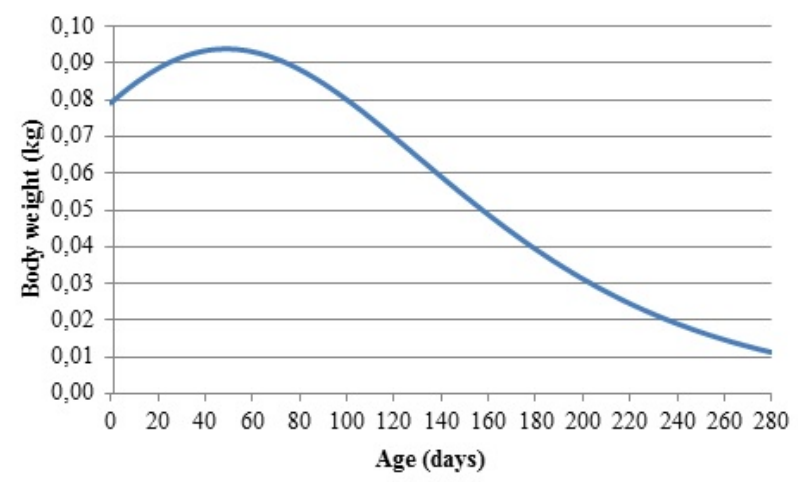

Repartida goats are known to have a reduced growth rate compared to goats of other breeds. In the current study, the daily weight gain of the goats was small, however, their weight at the inflection point is consistent with other studies conducted using different goat populations. Malhado et al. (2008) studied Anglo-Nubian goats reared in the Caatinga region, and found that the AGR was crescent until it reached its maximum of approximately $0.130 \mathrm{~kg}$ per day, and the inflection point was reached at 71 days when the goats weighed approximately 10.7 $\mathrm{kg}$. Another studies using Mambrino goats, raised in the same Caatinga region of Bahia (Brazil), reported a crescent AGR of 0.146 ( 88 days) and 0.127 (72 days) $\mathrm{kg}$ per day for males and females, respectively, with the inflection point reached at 100 days for males and 83 days for females, where their weights were 15.1 and $9.9 \mathrm{~kg}$, respectively (CARNEIRO et al., 2009).

The results obtained for the AGR indicate that the maximum growth rate was achieved early, when goats were just over two months of age, at which the animals had reached their highest growth speed. The AGRs were very small at the end of the analyzed period, suggesting that these animals barely gained any weight from 7 months of age. Therefore, goats can be slaughtered from 210 days as their weight gain is reduced after that age.

The decrease in AGR may be a consequence of a poor management. Thus, improvements in feed management should be made in order to improve the weight gain of the animals, especially during this phase. The results of this study may indicate adaptations of these animals to the Caatinga of Bahia (Brazil), where the Repartida goats follow this growth pattern. Although these goats have a high growth rate when young, their growth rate decreases with increasing age, resulting in a lower weight in adulthood.

The analysis of variance of the logistic model revealed that the $A$ and $m$ parameters were notaffected by the environment for the contemporary groups, sex 
or type of birth. The effect of contemporary groups was only significant for the estimated parameter $k(\mathrm{P}$ $<0.05$ ), which demonstrates the influence of food seasonality on the estimated parameters, resulting in an altered growth pattern of the kids. This may indicate that, even with the adopted management in the local, the indirect effects of the climate were probably minimized, but not completely eliminated.

The estimated correlation between the $A$ and $k$ parameters was significant $(\mathrm{P}<0.01)$ and equal to -0.56 , confirming the results obtained by Carneiro et al. (2009) for goats, and the results obtained by McManus et al. (2003) and Sarmento et al. (2006) for sheep. McManus et al. (2003) pointed out that the most important biological relationship for the growth curve is between the $A$ and $k$ parameters. The negative correlation between these two parameters shows that animals with a higher growth rate are less likely to achieve a higher weight when mature compared to animals with a slower growth rate in early life.

\section{Conclusions}

In this study, we found that the logistic model showed the best fit for describing the growth curve. There was a sharp decrease in the absolute growth rate after weaning, therefore, nutritional strategies should be implemented during this period to alleviate the poor weight gain during this phase. Goats of the Repartida ecotype had a high body weight at birth but low body weight at maturity, which may demonstrate, in addition to a nutritional deficit, the adaptation of these animals to the adverse conditions of the Caatinga region (Brazil). The growth rate of these animals at maturity is very slow, therefore, they can be slaughtered before 210 days of age.

\section{Acknowledgments}

The authors thank the University of Southwest of Bahia, the Bahia Company of Agricultural
Development and the Nacional Institute of Science and Technology of Animal Science (Instituto Nacional de Ciência e Tecnologia de Ciência Animal, INCT-CA) for allowing data collection and implementation of this work.

\section{References}

BRODY, S. Bioenergetics and growth. New York: Reinhold Publication Corporation, 1945. 1023 p.

CARNEIRO, P. L. S.; MALHADO, C. H. M.; AFFONSO, P. R. A. M.; PEREIRA, D. G.; SUZART, J. C.; RIBEIRO JÚNIOR, M.; SARMENTO, J. L. R. Curva de crescimento em caprinos da raça Mambrina, criados na caatinga. Revista Brasileira Saúde e Produção Animal, Salvador, v. 10, n. 3, p. 536-545, 2009.

DOMINGUES, O. Introdução à zootecnia. Rio de Janeiro: SIAMA, 1941. 392 p.

FREITAS, H. Criação de caprinos. Rio de Janeiro: SIAMA, 1951. $179 \mathrm{p}$.

INSTITUTO NACIONAL DE METEOROLOGIA INMET. Normais climatológicas do Brasil 1961 - 1990. Brasília: INMET, 2009. Disponível em: <http://www. inmet.gov.br>. Acesso em: 21 out. 2016.

INSTITUTO BRASILEIRO DE GEOGRAFIA E ESTATÍSTICA - IBGE. Pesquisa Pecuária Municipal. Rio de Janeiro: IBGE, 2014. Disponível em: <http:// brasilemsintese.ibge.gov.br/agropecuaria/efetivos-dapecuaria.html>. Acesso em: 4 ago. 2016.

LAIRD, A. K. Dynamics of relative growth. Growth, Bar Harbor, v. 29, n. 3, p. 249-263, 1965.

MACHADO, T. M. M. Raças raras de pequenos ruminantes. Revista Ação Ambiental, Viçosa, MG, v. 3, n. 15, p. 19-23, 2001.

MACHADO, T. M. M.; MACHADO, M. M. M. The geographic localization of local goat populations. In: GLOBAL CONFERENCE ON CONSERVATION OF DOMESTIC ANIMAL GENETIC RESOURCES, 5., 2000, Brasília. Anais... Brasília: EMBRAPA/RBI, 2000. CD-ROM.

MALHADO, C. H. M.; CARNEIRO, P. L. S.; CRUZ, J. F.; OLIVEIRA, D. F.; AZEVEDO, D. M. M. R.; SARMENTO, J. L. R. Curvas de crescimento para caprinos da raça Anglo-Nubiana criados na caatinga: rebanho de elite e comercial. Revista Brasileira Saúde e Produção Animal, Salvador, v. 9, n. 4, p. 662-671, 2008. 
McMANUS, C.; EVANGELISTA, C.; FERNANDES, L. A. C.; MIRANDAI, R. M.; MORENO-BERNALI, F. E.; SANTOS, N. R. Curvas de crescimento de ovinos Bergamácia criados no Distrito Federal. Revista Brasileira de Zootecnia, Viçosa, MG, v. 32, n. 5, p. $1207-$ 1212, 2003.

MONTEIRO, A. M. C.; AZEVEDO, J. M. T.; SILVA, E. S. R. Curvas de crescimento de caprinos machos da raça Serrana Transmontana. Revista Portuguesa de Zootecnia, Vila Real, v. 5, n. 2, p. 35-41, 1998.

NELDER, J. A. The fitting of a generalization of the logistic curve. Biometrics, Texas, v. 17, n. 1, p. 89-110, 1961.

OLIVEIRA, D. F.; CRUZ, J. F.; CARNEIRO, P. L. S.; MALHADO, C. H. M.; RONDINA, D.; FERRAZ, R. C. N.; TEIXEIRA NETO, M. R. Desenvolvimento ponderal e características de crescimento de caprinos da raça Anglo-Nubiana criados em sistema semi-intensivo. Revista Brasileira Saúde e Produção Animal, Salvador, v. 10, n. 2, p. 256-265, 2009.

OLIVEIRA, H. N.; LÔBO, R. B.; PEREIRA, C. S. Comparação de modelos não-lineares para descrever o crescimento de fêmeas da raça Guzerá. Pesquisa Agropecuária Brasileira, Brasília, v. 35, n. 9, p. 18431851, 2000.

OLIVEIRA, J. A. Avaliação da curva de crescimento e a utilização de modelos de regressão aleatória em caprinos da raça Alpina. 2011. Dissertação (Mestrado em Zootecnia) - Curso de Pós-Graduação em Zootecnia, Universidade Federal de Viçosa, Viçosa, MG.
RICHARDS, F. J. A flexible growth function for empirical use. Journal of Experimental Botany, Lancaster, v. 10, n. 2, p. 290-300, 1959.

SARMENTO, J. L. R.; REZAZZI, A. J.; SOUZA, W. H.; TORRES, R. A.; BREDA, F. C.; MENEZES, G. R. O. Estudo da curva de crescimento de ovinos Santa Inês. Revista Brasileira de Zootecnia, Viçosa, MG, v. 35, n. 2, p. 435-442, 2006.

SARMENTO, J. L. R.; SOUZA, J. E. R.; SOUSA, W. H.; SOUZA, M. S. M.; REGO NETO, A. A.; SANTOS, G. V. Estimativas de parâmetros de curvas de crescimento de caprinos da raça Anglo-Nubiana. In: SIMPÓSIO BRASILEIRO DE MELHORAMENTO ANIMAL, 7., 2008, São Carlos. Anais... São Carlos: Sociedade Brasileira de Melhoramento Animal, 2008. p. 1-3.

SILVA, F. L. R.; ARAÚJO, A. M. Desempenho produtivo em caprinos mestiços no semi-árido do nordeste do Brasil. Revista Brasileira de Zootecnia, Viçosa, MG, v. 29, n. 4, p. 1028-1035, 2000.

SOUZA, J. C.; BIANCHNI SOBRINHO, E. Estimativas do peso de bovinos de corte, aos 24 meses, da raça Nelore usando curvas de crescimento. Revista Brasileira de Zootecnia, Viçosa, MG, v. 23, n. 4, p. 85-91, 1994.

STATISTICAL ANALYSIS SYSTEM INSTITUTE SAS Institute Inc. SAS/STAT. User's guide. Version 8.1. Cary: SAS Institute, 1999.

von BERTALANFFY, L. Quantitative laws in metabolism and growth. The Quarterly Review of Biology, New York, v. 32, n. 3, p. 217-230, 1957. 
